\title{
THE FEASIBILITY OF INDONESIAN SCIENTIFIC-BASED LEARNING MODULE WITH TIME TOKEN AREND METHOD
}

\author{
Nurul Komariyah ${ }^{1 *}$, Salati Asmahasanah ${ }^{2}$, Kamalludin $^{3}$ \\ ${ }^{1,2,3}$ Primary School Teacher Education Department \\ Universitas Ibn Khaldun, Bogor, Indonesia \\ "Email: nurulkmryh13@gmail.com
}

\author{
Website: \\ https://jurnal.uinantasari.ac.id/index.php/adzka \\ Received: 6 October 2020; Accepted: 13 February 2021; Published: 23 June 2021 \\ DOI: $\underline{\text { 10.18952/aladzkapgmi.v11i1.3993 }}$
}

\begin{abstract}
This study aims to determine the feasibility of teaching materials in the form of scientific- based learning modules with the Arend Time token learning method, where the steps of this learning activity are designed so that students are actively involved in the learning processand carry out the social interaction process with other friends and can contribute actively. This study used Research and Development (R \& D) with the Sugiyono method which consisted of 10 stages, however the researcher only used 7 stages due to the current state of Covid-19. These stages are (1) potential and problems, (2) data collection, (3) product design, (4) design validation, (5) design revision, (6) Product Revision, then followed by (7) limited production. Then the module is validated by experts consisting of design, material, and language experts using a questionnaire in the form of a validation sheet. The result of this research is that the percentage of eligibility results of design experts is $81.25 \%$ with very valid categories, $93 \%$ material experts with very valid categories, and linguists of $84.61 \%$ with very valid categories. So it can be concluded that the scientific- based Indonesian learning module with the time token method for grade IV SD / MI is feasible to use to make students actively involved in the process of learning activities.
\end{abstract}

Key Words: module; scientific; time token arend method

\section{INTRODUCTION}

Indonesian is one of the compulsory subjects in Elementary Schools. Language has its role in every human activity in the world because language is a very important tool for the communication process which is one of the supporting activities for the interaction of everyone in everyday life. It is almost certain that in everyday life it is inseparable from communication activities between a person and one group and another. Therefore, Indonesianis one of the subjects that requires students to be actively involved in the learning process. In learning Indonesian, students need to be invited to play an active role during the learning process, such as being active in observing/identifying, asking questions, gathering information, analyzing, and being able to be active in communicating what they have found.It is intended that students do not just get knowledge from the teacher alone, but students can interact with the surrounding environment and seek information independently.

In this regard, education can be said to be good if it has a good curriculum as well. A curriculum is an important tool because it forms the basis of a learning process. The curriculum is the main tactic for achieving success in education. The existing curriculum in Indonesia often changes, this also aims to fix the education system which is expected to makeindividuals 
more proactive, creative, and innovative through their knowledge, attitudes, and skills.

As the purpose of education (Kemdiknas): in "Law Number 20 of 2003 concerning the National Education System, Article 3, the aim of national education is to develop the potential of students to become human beings who believe and fear God Almighty, have noble, healthy, moral character, knowledgeable, competent, creative, independent, and a democratic and responsible citizen. Meanwhile, the purpose of education in Islam is to get closer to Allah and Islamic teaching emphasizes morals. In general, Islamic education aims to foster children, be competent in science, skilled in working in society, foster thinking and morals, teach culture, create personality, devote themselves to Allah and prepare students for their life provisions in the world and the hereafter. (Faturrahman, et al 2012: 64 \& 72).

In connection with the educational objectives above, according to (Faturrahman, et al, 2012: 165) In learning activities, a teacher has an important and major role in determining the quality of teaching he/she carries out. Namely providing knowledge (cognitive), attitudes and values (affective), and skills (psychomotor). In other words, the main task and role of an educator are in the field of teaching. Teaching is one of the tools to achieve learning goals. Therefore, an educator is required to be able to manage the class well, especially in developing teaching materials properly so that students are interested in listening to learning and can master the learning objectives they want to achieve.

There are many learning resources that can be used by educators and students to improve their abilities and increase their knowledge. Teaching materials are a form of learning resources that are able to support students to achieve competency standards andbasic competencies and achieve predetermined learning objectives.

According to the Ministry of National Education (2008) in (Renat et al., 2017) states that "a module is a book written with the aim that students can learn independently without or with teacher guidance. So in the module already contains material, methods, instructions for learning activities, exercises, and how to evaluate which are well structured, which means that students can learn independently and the teacher is only a facilitator, where students are involved to be active in the learning process.

In connection with things above, to carry out assignments professionally, a teacher can also make teaching materials by collaborating one of the learning approaches and learning methods that can attract students' attention and involve students actively in the learning process. The learning method is the spearhead needed by the teacher in a lesson because the method is several steps designed to achieve certain teaching goals.

The approach that can be used to increase student activeness in the learning process is to use a scientific approach. As for this, according to Daryanto (2014: 51) the concept of the scientific approach is a learning process designed in such a way by the teacher so that it can actively involve students in constructing concepts, laws, or principles through the stages of observing, formulating problems, proposing or formulating hypotheses, collect data, analyze data, draw conclusions and communicate concepts that have been found or what is often known as learning using the $5 \mathrm{M}$ process. In addition, the learning approach also can be collaborated with interesting learning methods, one of which is the learning method time token ARend. This method is a method that applies democratic methods in schools. The democratic learning process is a learning process that places students as subjects. Throughout the learning process, student activities are the main concern. In other words, they are always

actively involved. The teacher plays a role in inviting students to find solutions together to problems encountered by Arend, 1998 in the book Huda, (2014: 239).

However, in reality, the books used by grade IV in several SD / MI in Bogor City so far have not fully adapted to the needs of students. The books used are written activities that involve students actively, but in fact, only a few students are active, most of them are very disinterested and even quickly feel bored because it is not appropriate with the conditions andneeds of the 
students. In addition, in the presentation of books that are less attractive so that students feel lazy to learn them, this can be seen from the books used that emphasize more onstudents reading theories then copying or working on them. As a result, there is a lack of deeper understanding of students during the learning process, which causes boredom in students. In research conducted by Irma Damayanti (2017) states that the validation results of the validators, the scientific approach-oriented module developed by the researcher can be said to be very valid by including validity criteria expressed with a value of 3.5, then it is saidto be effective by looking at the student test results. which amounted to 30 students, namely

$\Sigma=83 \%$, then the results of the student response were effective in bringing students to master competencies and effectively attracting student interest in learning.

In addition, the research of Tika Sulistiawati (2017) states that there is a significant influence between the use of the learning model time token on the speaking ability of class III students of MIN 7 Bandar Lampung. From some of these explanations and the problems found, the researcher intends for innovations that can be made by the teacher, one example is through developing a scientific- based Indonesian learning module with the method of time token arend for grade IV SD / MI. This research focuses on developing a scientific-based Indonesian learning module with the method of time token arend with the material "Fiction Stories" which is expected to attract students' attention to be more active in carrying out learning activities.

\section{RESEARCH METHOD}

The method used in this research is Research and Development (R\&D) or research developed by Sugiyono (2018: 298). According to Sugiyono (2018: 297) R\&D is a research method used to produce certain products and test the effectiveness of these products. Meanwhile, according to Borg and Gall (1983: 772) in (Hanafi, 2017) R\&D is one of the ways or ways used to develop and validate an educational product.

This research was conducted in class IV MI Yapendi Bogor when this research was conducted for 3 months starting from June-August 2020. The development of teachingmaterials in the form of this learning module used research stages according to Sugiyono, namely 1) Potentials and Problems, 2) Data Collection, 3) Product Design, 4) Design

Validation, 5 ) Design Revision, 6) Product Testing, 7) Product Revision, 8) Usage Trial 9) Product Revision, and 10) Mass Production. However, the researchers limit the use of only seven steps from the ten steps because of the limited time, cost, and all the six steps can answer the existing problem formulation. The steps are described in Figure 1 below:

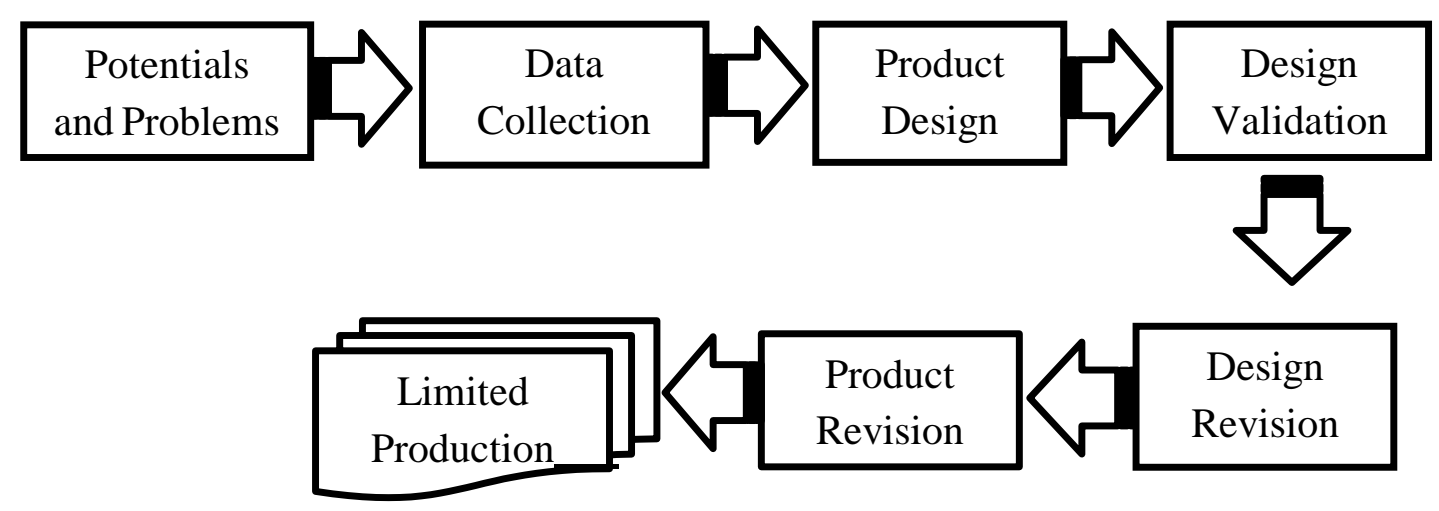

Figure 1. Stages of Feasibility R\&D Steps for Scientific Module Time Token ArendMethod of Sugiyono (2018: 298) 


\section{Potentials and Problems}

At this stage, the researcher will collect previous studies that mention the potential use of scientific-based learning modules with the method of time token ARend in Indonesian language learning. Then, look for previous studies that use scientific-based learning methods with the ARend time token method in terms of Indonesian language learning which can support the activeness of grade IV SD / MI students in the learning process.

2. Data Collection

At this stage, data collection is carried out in the form of information which will later be used as a source in the knowledge of scientific-based learning modules with the method of time token ARend which refers to the stages of learning Indonesian which can make students active and be able to apply the 5M learning contained in scientific approach, namely observing, asking questions, gathering information, analyzing and communicating. The data collected is in the form of booksrelated to the scientific approach and the learning method of time token arend as well as Indonesian language learning materials for grade IV SD / MI with Fiction Story Text material that supports active learning as well as various journals and other references related to the development of scientific-based learning modules with the method of time token arend to form active students.

3. Product Design

At this stage, the researcher carried out a design with reference and obtained in the previous stage, namely by paying attention to the potential stages and problems with the process of making a product in the form of a learning module which was thendeveloped to become a guide for the learning activities of grade IV SD / MI students.

4. Design Validation

At this stage, it is carried out to see to what extent this module can help the student learning process in Indonesian language lessons. Also used to determine the extent to which the developed module can run as expected. This validation stage can be done by bringing in several validators or experts who are experts in their fields and have experience in providing an assessment of the new product that has been designed. Validation is carried out by several validators,

including 1 validation of material experts, 1 validation of linguists, and 1 validation ofdesign experts who aim to obtain suggestions for improving the developed module.

5. Design Revision

After the design product is finished and checked by other validators, then the weaknesses will be found. At this stage, the weakness is then reduced by repairing it by the researcher while still paying attention to the suggestions for improvement obtained from the experts as well as in the previous stages.

6. Product Revision

After design improvements have been made, then the product needs to be repaired again to fix the deficiencies of the product. These deficiencies are then corrected in order to create a better product.

7. Limited Production

At this stage is to produce modules that have been developed by sending files via email to class IV SD / MI teachers due to time and cost limitations.

The product validation analysis is in the form of this learning module by design, material, and language experts. The steps are as follows:

1. The quantitative data from the Likert scale on the expert evaluation sheet was converted into qualitative data.

2. Tabulate all the data that has been obtained for each component, the sub-components of the assessment items available in the instrument. The formula for finding the percentage is as follows: 
Information :

$$
\text { Percentage }=\frac{F}{N} \times 100
$$

$\mathrm{P} \quad$ : percentage number

$\mathrm{F} \quad$ : frequency that being searched

$\mathrm{N} \quad$ : total number of frequencies/number of individuals

With the following assessment criteria:

Table 1. Interval Percentage

\begin{tabular}{|c|c|c|}
\hline \multicolumn{3}{|c|}{ Criteria of Eligibility } \\
\hline Percentage & Qualifications & Eligibility Criteria \\
\hline $81 \%-100 \%$ & Very Valid & No Revision \\
\hline $61 \%-80 \%$ & Valid & No Revision \\
\hline $41 \%-60 \%$ & Quite Valid & Little Revision \\
\hline $21 \%-40 \%$ & Less Valid & Revision \\
\hline $0 \%-20 \%$ & Very Less Valid & Total Revision \\
\hline
\end{tabular}

The data of this research, the percentage of eligibility is determined by a percentageof $41 \%$ $60 \%$ with the category "Enough Valid". So, if the results of the assessment by experts the average score gets a percentage of $41 \%-60 \%$, then the product in the form of a scientificbased Indonesian language learning module with the time token method for class IV SD / MI is considered "Worth Using".

\section{RESEARCH RESULTS AND DISCUSSION}

Based on the research results, the learning module was assessed by a team of validation experts in their respective fields. This validation test is carried out by design experts, material experts, and linguists to find out the feasibility of a learning module that has been made. However, even though the learning module has been declared valid, the expert team still provides comments and suggestions for the learning module to be better. The following are the results of the learning module assessment:

Table 2. The Results of Learning Module Assessment

\begin{tabular}{|c|c|c|}
\hline \multicolumn{3}{|c|}{ The Results of Learning Module Assessment } \\
\hline Validator & Percentage & Information \\
\hline Design Expert & $81,25 \%$ & Very Valid \\
\hline Material Expert & $93 \%$ & Very Valid \\
\hline Linguist & $84,61 \%$ & Very Valid \\
\hline
\end{tabular}

Based on Table 2. Assessment from experts designs that were validated by design experts, namely Ms. Maimunah, M.Pd, obtained a percentage of the feasibility level of $81.25 \%$ with a very valid category. As for comments and suggestions were given by design experts, the use of images must be appropriate with the content of the material, the use of lines in the cover does not need to be used, the images used do not need to be too many, then the validator also provides suggestions, changing the background color to a more standard color/soft color, design experts also suggest using the typeface Book Antiqua or Century, and the placement of the image is more enlarged because it relates to the discussion as in Figure 2. below: 

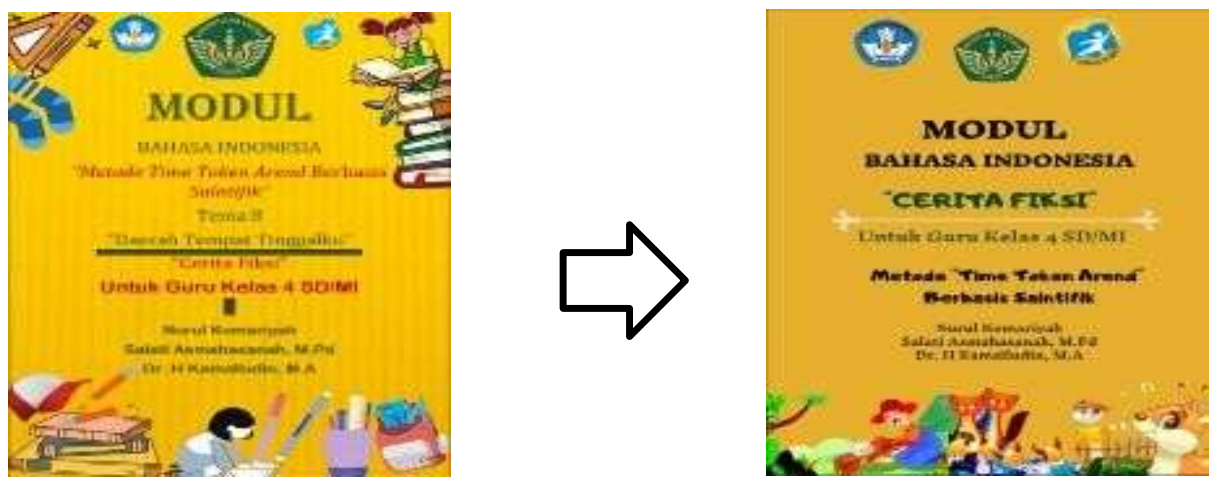

Figure 2. Before and After Revision

Furthermore, the expert assessment of the material validated by the MI Yapendi Bogor Teacher, namely Mrs. Dita Hildayatni, S.Pd, obtained a percentage of the feasibility level of 93\% with a very valid category. As for the comments and suggestions were given by design experts, the lack of ability to ask questions for students, examples, and cases have not been seen in everyday life. The validator also provides suggestions for examples in everyday life that can take from the positive or negative values in the stories contained in this module, and besides that, the validator also provides comments regarding the Learning Implementation Plan (RPP), it should be more clarified that the meeting of each chapter by making one lesson plan for each module 1 and module 2.Therefore, the researcher improves it by adding the parts suggested by the validator into the learning module as shown in Figure 3 below:
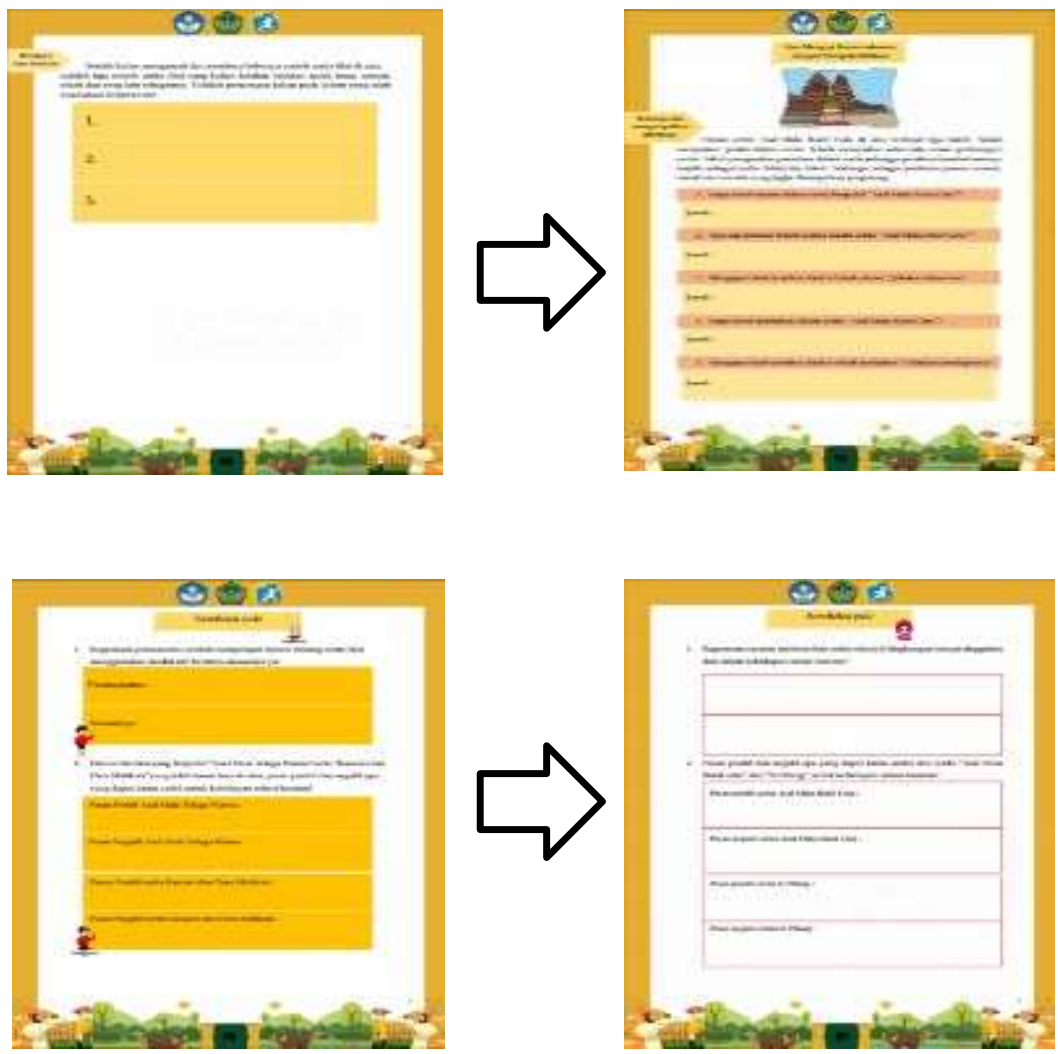

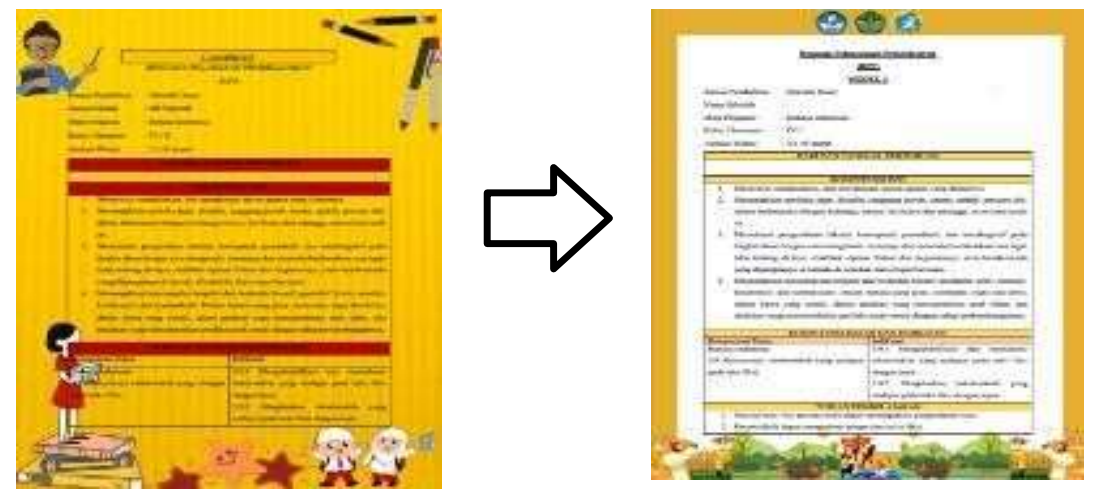

Figure 3. Before and After Revision

The last assessment of the linguist validated by the linguist, Mr. Andesten, M.Pd, obtained a percentage of the feasibility level of $84.61 \%$ with a very valid category. The validator provides suggestions for correcting typo or wrong words, choosing words accordingto (EYD) which are good as in the evaluation module "After you have worked on independent practice questions and worked together with your group members during discussion activities, now is the time for you to test your knowledge. The way to do this activity is to choose one of the answers that you think is the most appropriate by putting a cross ( $\mathrm{x}$ ) on the letters $\mathrm{a}, \mathrm{b}, \mathrm{c}$, or d "to" After you have done the independent practice questions and collaborated with your group members, now it's time for you to test your knowledge Answer the following questions that you think are most appropriate and correct by putting a cross ( $\mathrm{x}$ ) in the choice of letters $\mathrm{a}, \mathrm{b}, \mathrm{c}$ or $\mathrm{d}$ "and including the source of the reading used in each explanatory text of the material as shown in Figure 4 below:
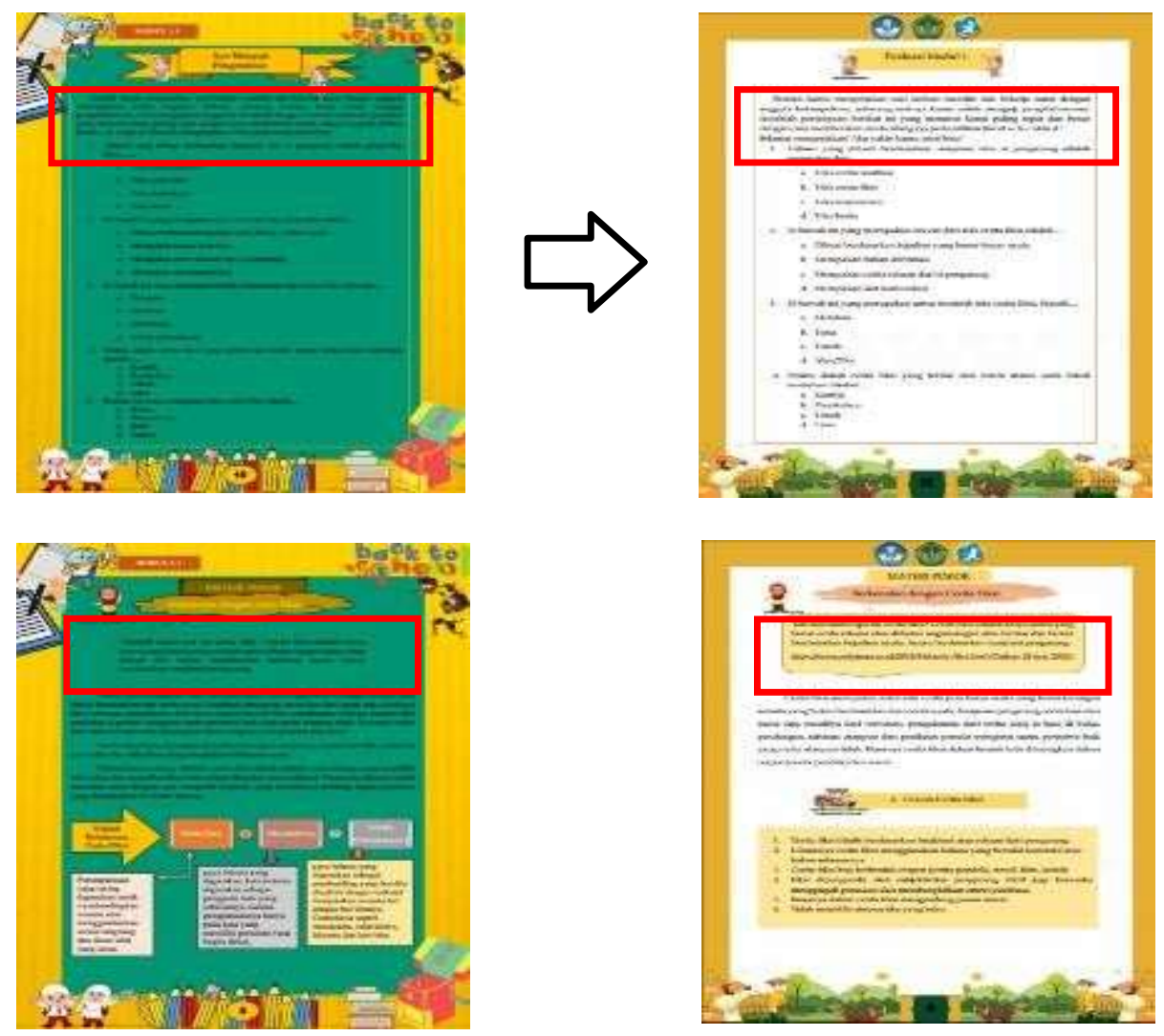

Figure 4. Before and After Revision 
According to the results obtained, this learning module is feasible to use. This module has been assessed by a team of experts consisting of 3 validation experts, namely design experts, material experts, and linguists. The assessment criteria used to refer to the assessment criteria issued by the Indonesian National Standard Agency (BNSP). The results obtained indicate that the product in the form of a learning module is included in the Very Valid (Very Good) category by looking at the guidelines for the percentage of eligibility determined by a percentage of $41 \%$ - 60\% with the category "Enough". So, if the results of the assessment by the experts' score reach a percentage of $41 \%-60 \%$ then it is declared "Good" or suitable for use.

This learning module Scientific with the method of time token arend is not only presenting material in general but also including several steps of scientific learning that involve students to be actively involved in the learning process (Musfiqon and Nurdyansyah, 2015: 37). The scientific approach is one of the concepts designed and used by educators in order to actively involve students in the learning process by solving a given problem individually through discussion activities. In this learning module students will observe (Observing), ask (Question), collect information, process information/reason, then conclude, or what is often known as the $5 \mathrm{M}$ concept. The scientific approach also aims to make students understand that the new knowledge they can learn from anywhere, not only from a teacher, they can also understand the material with scientific processes. Daryanto (2014: 51).

This scientific approach is collaborated with learning methods that can support the learning method of time token arend. The method of time token arend is one of the methods that apply democratic learning in schools to train students to develop social skills that involve speaking activities, with this method all students are required to be active to speak inexpressing opinions or to convey the results of the discussion process with group members. All students will talk because all students will be distributed cards so that students have totalk for 30 seconds alternately until the cards run out (Mukrimah, 2014: 118). In this learning,students will be the main point of attention because they will be actively involved in the process of learning activities. In this module, students must also experience a change in a more positive direction, so that this scientific approach is very suitable to be combined with the method of time token arend. This aims to make all students believe that they can be actively involved in the learning process and be more confident. In addition, there are steps for using the collaboration module between the scientific approach and the method of time token arend which involves students actively, in this learning module there are also instructions to guide students in carrying out discussion activities, there are sheets to test students' accuracy, there are student evaluation sheets, answer keys, and there are reflective sheets for students about positive and negative messages can be taken and applied in the dailylife of students taken from the various fictional stories in the module.

Based on the explanation of the module, the results of the validation that have been given by the design expert are obtained. The percentage results are $81.25 \%$ with the category "Very Valid". In addition to obtaining an assessment from a design expert, the validator also conveyed his suggestions and input, namely, the use of images must be appropriate with the content of the material, the use of lines in the cover does not need to be used, the image used does not need to be too much, the background color should use a color that is not too bright. more standard colors / soft colors, the font is recommended to use Book Antiqua or Century, and the placement of the image is more enlarged because it involves the discussion. Comments and suggestions from design experts have been improved so that this learning module looks tidier. This learning module is declared feasible because the learning module design looks attractive to be used by students in learning it. Using this module also raises students' interest in learning it.

The next assessment is by material experts. The expert's evaluation of the material obtained results of $93 \%$ with the category "Very Valid". In addition to providing material expert 
assessments, they also provide comments and suggestions, namely, the lack of the ability to ask students, there are no examples and cases in everyday life, the validator also provides suggestions for examples in everyday life that can take from positive or negative values. In the stories contained in this module, and besides that the validator also provides comments regarding the Learning Implementation Plan (RPP), the meeting of each chapter should be more clarified. Comments and suggestions from material experts have been improved so that this learning module is appropriate to be used as a learning guide.

The last assessment is by a linguist. The linguist's assessment results were $84.61 \%$ with the category "Very Valid". In addition to providing an assessment, the linguist also provides comments and suggestions, which are correcting typos or wrong words, choosing words according to (EYD), and including the source of the reading used in each explanatory text of the material. Comments and input from linguists have been corrected so that the scientificbased Indonesian learning module with the time token method for grade IV SD / MI is feasible to be used as teaching material and can be utilized.

\section{CONCLUSION}

Based on the results of the research, it can be concluded that the product has been produced in the form of a scientific-based Indonesian learning module with the time token method for class IV SD / MI which is good and feasible to be used as teaching material and can be used. The research was obtained based on the results of validation by design experts, material experts, and linguists. The results of the assessment by design experts reached the "Very Valid" category with the percentage of the value obtained amounting to $81.25 \%$. The results of the assessment by material experts reach the "Very Valid" category with the percentage of the value obtained is $93 \%$. The results of the assessment by linguists with a percentage of the value obtained are $84.61 \%$ in the "Very Valid" category. This shows that the module developed is good and feasible to be used as a teaching material or media that canbe used in a lesson.

\section{REFERENCES}

Achmad, Sri Wintala. 2015. Bahasa dan Sastra Indonesia Pedoman Praktis Menulis Dalam Bahasa Indonesia. Yogyakarta: Araska.

Aditia, M. Taufik \& Muspiroh, N. 2013. Pengembangan Modul Pembelajaran Berbasis Sains, Lingkungan, Teknologi, Masyarakat Dan Islam (Salingtemasis) Dalam Meningkatkan Hasil Belajar Siswa Pada Konsep Ekosistem Kelas X Di SMA NU (Nadhatul Ulama) Lemahabang Kabupaten Cirebon. Scienticiae Educatia, 2(2), 1-20.

Alek. H. Achmad. 2010. Bahasa Indonesia Untuk Perguruan Tinggi. Jakarta: Prenada Media Group.

Daryanto, 2014. Pendekatan Pembelajaran Saintifik Kurikulum 2013. Yogyakarta: Penerbit Gava Media.

Hanafi. (2017). Konsep Penelitian R \& D Dalam Bidang Pendidikan. Saintifika Islamica: Jurnal Kajian Keislaman, 4(2), 129-150.

Hanafi. 2017. Konsep Penelitian R \& D Dalam Bidang Pendidikan. Saintifika Islamica: Jurnal Kajian Keislaman, 4(2), 129-150.

Harta, I., Tenggara, S., \& Kartasura, P. 2014. Pengembangan Modul Pembelajaran untuk Meningkatkan Pemahaman Konsep dan Minat SMP. Pythagoras: Jurnal Pendidikan Matematika, 9(2), 161-174. https://doi.org/10.21831/pg.v9i2.9077

Hindun. 2014. Pembelajaran Bahasa Indonesia Berkarakter di Madrasah Ibtidaiyah/Sekolah Dasar. Depok: Nufa Citra Mandiri.

Huda, Miftahul. 2014. Model-Model Pengajaran dan Pembelajaran. Yogyakarta: Pustaka Pelajar.

Mukharim, Sifa Siti. 2014. 53 Metode Belajar dan Pembelajaran. Bandung: Bumi Siliwangi. 
Musfiqon, \& Nurdyansyah. 2015. Pendekatan Pembelajaran Saintifik. Sidoarja: Nizamia Learning Center.

Sugiyono.2018. Metode Penelitian Kuantitatif, Kualitatif, $R \& D$. Bandung:Alfabeta

Sulistiawati, T. (2017). Pengaruh Model Pembelajran Time Token Terhadap Kemampuan

Berbicara Siswa Pada Mata Pelajaran Bahasa Indonesia Kelas III MIN 7 Bandar Lampung. 1-97. http://repository.radenintan.ac.id/462/1/skripsi_tika.pdf

Yansyah, N. F., Asmahasanah, S., \& Hakiem, H. (2019). Pembelajaran Tematik Terpadu Melalui Pendekatan Saintifik Berbasis Lingkungan. Caruban: Jurnal Ilmiah Ilmu Pendidikan Dasar, 2(1), 40. https://doi.org/10.33603/.v2i1.2349. 
The Feasibility of Indonesian... 